Received February 16, 2019

Revised May 5, 2019

Accepted May 6, 2019

\title{
Sanctions, Security and Regional Development in Russia's Policies Toward North Korea
}

\author{
ANTHONY V. RINNA*
}

In light of North Korean security provocations, the Kremlin has consistently supported the UN's punitive economic measures against Pyongyang; even as economic collaboration with the DPRK is part of a Russian bid to economically invigorate the Russian Far East. This paper argues that Moscow has faced a choice between pursuing its own interests in terms of bilateral relations with the DPRK and participating in a collaborative manner with other states involved in the Korean security debacle, opting for the latter. Even as North Korea is a crucial part of Russia's plans to economically develop its Asiatic territories, the Kremlin perceives that it cannot refuse to join other countries in implementing punitive measures against Pyongyang, even while inconveniencing its own economic interests.

Keywords: Economics, Korea, Russia, Sanctions, Security

*Senior Editor, Sino-NK; E-mail: anthony.v.rinna@gmail.com DOI: 10.16934/isr.20.1.201906.21 


\section{INTRODUCTION}

The Russian Federation has consistently striven to be an active participant in resolving the Korean security crisis, while in more recent years Moscow has developed increasing political will toward shoring up its bilateral ties with the DPRK, particularly in the realm of economics. Moscow's push to strengthen ties with Pyongyang constitutes part of the Kremlin's so-called "turn to the East." Russia's Asiatic pivot is designed to increase Moscow's influence in East Asia independent of China, while on the domestic front, the Kremlin aims to develop the Russian Far East (Mankoff 2015, 67-68). Although economic considerations by-and-large undergird the "pivot to the East," both in terms of Moscow's ties to other states as well as the domestic factors driving Russian policy emphasis on the Asia-Pacific, security also factors heavily insofar as stability is necessary for Russia to realize its economic goals in Asia. For Russia's policies toward North Korea, economics and security are inseparable.

Dynamics surrounding the security situation on the Korean Peninsula pose significant challenges for Moscow's foreign policy and domestic ambitions in the eastward trajectory of the Russian government's policies. In terms of traditional security and interstate relations, the Korean security crisis presents the risk of armed violence on the Russian periphery, which in Moscow's view inhibits Russia's ability to pursue economic projects on the Korean Peninsula, thus undermining avenues for the development of the Russian Far East. Compounding this, the Korean security debacle has led Moscow to take actions that undermine Russian economic interests' vis-à-vis North Korea, namely in approving the laying of sanctions against the DPRK. Particular to the Korean security crisis, Russia faces the task of proving that it is a constructive player in Korean security, and that Moscow's own narrow interests do not undermine those of the international community. Maintaining legitimacy and credibility among the community of states involved in the Korean security debacle is of particular interest for the Russian Federation (Gabuev 2017, 251). Nevertheless, economic sanctions prevent Russia from pursuing closer relations with North Korea, undermining opportunities for Moscow-Pyongyang cooperation that could help develop the Russian Far East.

The Russian government has long called for the DPRK to denuclearize, viewing North Korea's possession of weapons of mass destruction as jeopardizing Northeast Asian regional stability. Yet, the Russian government's public calls for denuclearization on the Korean Peninsula notwithstanding, many Russian officials and experts privately assert that Korean denuclearization is not a realistic goal. Furthermore, the Russian government does not view North Korea's weapons of mass destruction to be a direct threat to Russia's national security (Gabuev 2017, 250). Indeed, even as the Russian government remains officially opposed 
to North Korea's nuclear status, Moscow by and large considers North Korea's real, if unrecognized, nuclear status to be a fait accompli and sees denuclearization as untenable for the foreseeable future (Lukin 2017, 64). For Russia, the greatest danger from the DPRK's WMD capabilities is the fact that miscalculations could prompt the outbreak of armed violence on the Russian periphery, which could lead to such undesirable developments as the US taking military action against the DPRK (Weitz 2015, 4).

Nevertheless, the Kremlin has consistently assented to sanctions packages against Pyongyang at the UN Security Council. One potential reason behind the Russian Federation's support for sanctions in spite of Moscow's economic interests and its growing relationship with the DPRK is because it is the only way for Moscow to maintain a constructive presence among the other major players in the Korea crisis (Gabuev 2017, 255). In this view, Russia actually has more to lose by failing to support sanctions against the DPRK than it does by defying the international community by refusing to support punitive economic measures in light of the DPRK's recent provocations. Another driving force behind Moscow's decision to support sanctions against the DPRK is the Kremlin's global-level support for nuclear non-proliferation (Zakharova 2016b, 221).

Yet in spite of the Russian Federation's approval of sanctions against Pyongyang, North Korea has supported Russia diplomatically on international issues such as the annexation of Crimea in 2014 (The Moscow Times 2017), which may explain why, despite Russia's support for punitive economic measures, North Korea refrains from complaining to an extent that would disrupt ties with Russia. The purpose of this paper is to demonstrate the connection between the regional security considerations Russia faces as well as Russia's own domestic economic interests in light of the Korean security crisis. In the context of Korean security, the Russian Federation must balance between participating in international measures designed at mitigating the North Korean security threat and pursuing its own economic interests vis-à-vis the Korean Peninsula.

\section{NORTH KOREA-RUSSIA ECONOMIC TIES}

Post-Soviet Russia, particularly in economic terms, remains firmly oriented toward Europe and the post-Soviet space. During the administration of Russian president Dmitry Medvedev, the Kremlin initiated a drive aimed at increasing Russia's influence in the Asia-Pacific, a phenomenon that has come to be known as the "turn to the East." Moscow's emphasis on the Asia-Pacific trajectory of its foreign and domestic policies include solidifying closer relations with East Asian countries as well as integrating the Russian Far East economically with the vibrant economies of the Asia-Pacific. Some specific initiatives to this end include Russia's hosting of the annual Eastern Economic Forum in Vladivostok. 
One of the main facets of Russia's eastward pivot is developing the Russian Far East on the basis of "security by means of development." Based on this strategy, the Kremlin hopes to ensure the Russian Far East's economic security by integrating it with the rest of East Asia (Kozyrev 2014, 28).

During the twilight of the Cold War, the DPRK made a substantial shift in its political and economic orientation away from Moscow toward the PRC. In recent years, however the DPRK and the Russian Federation have continued their endeavors toward closer economic cooperation. In September 2012, the North Korean and Russian finance ministers signed an intergovernmental accord during which time the two sides discussed the possibility of constructing a pipeline traversing the Korean Peninsula connected to Russia, as well as taking steps to improve rail infrastructure at the Rason-Khasan Special Economic Zone (Mishin 2016, 64). North Korea and Russia subsequently expressed hope to expand the volume of their bilateral trade to one billion dollars by 2020, with Minister of Far Eastern Economic Development Alexander Galushka stating that agreements such as allowing the two sides to conduct trade in rubles would help boost trade (Primamedia.ru 2014). Likewise, in 2014 Russia officially canceled $90 \%$ of North Korea's Soviet-era debt. North Korea subsequently labeled 2015 to be a "Year of Friendship" with the Russian Federation, during which time the DPRK and Russia implemented mechanisms aimed at facilitating trade, including establishing a North Korea-Russia business council (RIA Novosti 2015). Attesting to the effects of the Russian "turn to the East" on Moscow-Pyongyang ties, the Ministry of Far Eastern Development (created in 2012 as part of Russia's eastward pivot) has been particularly instrumental in fostering the Russian Federation's relations with the DPRK (Troyakova 2016, 47).

Despite the Russian Federation's official support for punitive economic measures against Pyongyang at the UN, North Korea and Russia have continued striving for expanded economic ties. In the spring of 2018, for example, North Korean foreign minister Ri Yong Ho visited Moscow, while the following month Russian foreign minister Sergei Lavrov traveled to Pyongyang for an official visit. In both cases, the two sides discussed their plans for deepening commercial collaboration (Bardal, Demyanenko, Dyomina and Lomakina 2018, 21). Nevertheless, in spite of what appears to be a diligent effort in strengthening bilateral economic ties, the actual fruits of North Korea and Russia's striving appear to have yielded little. One stark example of this is how during the summit between Kim Jong Un and Vladimir Putin in April of 2019, the two sides did not sign any agreements on trade. Indeed, most of the DPRK-Russia economic relationship remains limited to cooperation in fields such as agriculture, construction, forestry, and light industry (Veka 2015, 185). Although engaging in these particular spheres has not been directly prohibited by UN sanctions, in the context of DPRK-Russia economic collaboration, these industries depend heavily upon a large workforce North 
Korean citizens employed in Russia, which the Russian government is obligated to phase out by the end of 2019 .

In and of itself, the value for Russia in strengthening economic ties with North Korea does not lie in the dollar amount of trade generated. Indeed, the volume of trade between the DPRK and the Russian Federation is quite small. Since reaching just over 100 million dollars in 2013, the volume of DPRK-Russia trade fluctuated between 68 million and 82 million until 2017 (Surinov et al. 2018, 488). In 2019, one presidential aide claimed that, due to sanctions, DPRK-Russia bilateral trade in 2018 amounted to only $\$ 34$ million (Tass 2019). Two of the main focal points of Russia's economic policy toward the DPRK is the realization of projects that mutually benefit North Korea and Russia, as well as Russian cooperation with South Korea as a partner in what Russia hopes will ultimately be a trilateral cooperative undertaking (Zakharova 2016a, 159).

Despite North Korea's own lack of economic prowess (especially in comparison with the economies of neighboring countries), the DPRK provides Russia with several potential economic opportunities of mutual benefit. North Korea offers Russia access to markets in the Asia-Pacific, especially by way of the North Korean port of Rason (together with the Russian town of Khasan forming the Rason-Khasan special economic zone). Moscow has repeatedly expressed interest in pursuing infrastructure projects with the DPRK, such as energy pipelines and railways that could mutually benefit North Korea and Russia. Russian access to the Korean Peninsula via terrestrial and maritime infrastructure could, in the event of greater economic and political rapprochement between the DPRK and South Korea could allow for South Korean commercial products to travel across Russian territory to other markets in Eurasia (Park, Tan and Govindasamy 2013, 138-139). The Russian Federation has already developed rail infrastructure such as including a rail line from Khasan to Rason. In 2014, meanwhile Russia proposed a deal whereby Russia would overhaul North Korea's national rail infrastructure in exchange for access to North Korea's mineral wealth (Akkalaeva 2014).

Trilateral cooperation between Moscow, Pyongyang and Seoul also constitutes a long-term goal of the Russian Federation's economic policies toward the DPRK. Russia, particularly compared with China, has been more willing to involve itself in multilateral economic cooperation with the two Koreas (Luzyanin and Zakharova 2015, 31). Indeed, China and Russia have exhibited somewhat differing approaches to economic cooperation with the Koreas in light of the DPRK's security provocations. After Pyongyang's first nuclear test in 2006, China was not only swift in condemning the test, but it was also reluctant to pursue investment in economic projects with the North. In contrast, Russia has been more consistent in pushing for economic cooperation projects with the DPRK (Park 2016, 26). 


\section{RUSSIA'S POSITION IN THE NORTH KOREAN SECURITY CRISIS}

The Russian Federation perceives North Korea's WMD to be a threat to regional security, a fact crucial for inter-state collaboration aimed at mitigating the Korean security crisis. As threats do not become securitized based on subjective perception, but rather based on inter-subjective agreement between states (Oelsner 2005, 3). The Russian Federation's official policy stance that the DPRK should denuclearize does not simply stem from regional concerns, but is part of Russia's global-level policy of stemming nuclear proliferation across the globe (Shin 2014, 138). Nevertheless, Russia's involvement in the Korean security crisis is concurrently related to Moscow's bid to increase Asiatic Russia's economic development and integration with East Asia.

Security drives Russia's support for UN sanctions, yet such support contradicts Russia's own domestic interests. One of the Kremlin's foremost policy goals in terms of the Korean Peninsula is to avoid the outbreak of violence, as conflict on the Korean Peninsula carries a huge risk for the Russian Far East's overall development. Russia has little ability to control the outcome of a conflict in Northeast Asia, yet Russia's Asiatic territories would be severely affected by large-scale violence (Blank 2015, 2). Russia experiences particular vulnerability near the Korean Peninsula, as any damage to the economic vitality of the Russian Far East could adversely affect the Russian Federation as a whole (Klimenko 2014, 44). Thus, even if the North Korean government does not threaten the Russian Federation directly, the specter of violent conflict in Northeast Asia endangers Russia's plans for economic development, prompting Moscow to join its international partners in inducing the DPRK to make significant policy changes regarding its possession of weapons of mass destruction.

A key factor in Russian security policy in Northeast Asia is the need to guarantee wholeness in regional security. Russia considers the security of the East Asia region to indivisible, and that it cannot be selective in nature. The Kremlin's outspokenness on Korean security, notwithstanding the Russian Federation's consistent striving to be an active player in Korean security has met with mixed success. From Pyongyang's point of view, however, Russia is not a particularly helpful partner in resolving the tensions over its nuclear program, insofar as Pyongyang's own interests are concerned (Denisov 2013, 47). During the second North Korea crisis from 2002-2006, Russia's main, undeclared goal during, was to see the preservation of the North Korean regime so that stability would be maintained on the Russian periphery (Fedorova 2018, 60). In 2012, Russian president Vladimir Putin stated that countries "cannot choose their neighbors," and that seeing as Russia and North Korea share a common border, the Russian government would "continue to work with the government of that 
country, working for good-neighborly relations while simultaneously bringing about a resolution to the nuclear problem (Zhebin 2013)."

From a more long-term standpoint, Russia's goals for resolving the Korean crisis includes: declaring Korea's nuclear-free status, ensuring strict observance of the NPT and that all sides fulfill their obligations, the maintenance of dialogue, security guarantees for the DPRK, and restoring economic and humanitarian programs on the Korean Peninsula (Denisov 2009, 113). The last point in particular is an area of DPRK-Russia mutual interest. The Russian government has asserted that a stable Korea can play a crucial part in developing Siberia and the Russian Far East; while conversely, the lack of security guarantees for North Korea undermines Russian economic interests (Weitz 2010, 7). Outside the realm of the Russian Federation's own narrow interests, economics and security on the Korean Peninsula are inextricably linked. Russia believes that cooperation with either North Korea itself, or in a trilateral format including the ROK, can only happen once the nuclear crisis is solved. That, in the Kremlin's view, cannot occur until North Korea received security guarantees to the point it perceives it does not need nuclear weapons (Samoilov and Sitnikov 2018, 194).

\section{SANCTIONS AGAINST THE DPRK AND CONSEQUENCES FOR ECONOMIC COOPERATION WITH RUSSIA}

Sanctions against the DPRK do not constitute a total loss for Moscow. If there is a high degree of economic interdependence between two states, then support for sanctions are unlikely to occur. Conversely, if a state does impose or support punitive economic measures on another state, then it is unlikely that there was ever any degree of economic interdependence in the first place (Letzkian and Souva 2007, 855). Indeed, Russia's decision to join in sanctions against the DPRK in 2017 left several areas of North Korea-Russia cooperation in science and technology unscathed (Stepanov 2018, 103).

Moscow has nevertheless remained skeptical about the efficacy of economic measures against the DPRK for two main reasons. First, the Russian Federation has expressed concerns that increasingly stringent sanctions could exacerbate the already deplorable humanitarian situation in North Korea, which could in turn cause instability in Korea and Northeast Asia (Lankov 2018). Second, Russia is wary that sanctions could undermine its ability to pursue its economic interests with the DPRK. At the heart of these two areas of concern is the Kremlin's desire to foster the economic development of the Russian Far East.

A stable East Asia with which Russia's Pacific territories are integrated is essential for Russia to realize its goal of strengthening the economic viability of its Far Eastern regions. If sanctions intensify the DPRK's economic isolation, however, in Moscow's view there is a risk of a loss of opportunities to connect the 
Russian Far East with the Korean Peninsula, as well as a greater threat of instability, the latter point in particular is why Russia has pushed for allowing humanitarian aid as outlined in Section 25 of UN Resolution 2397 (Tass.com 2018b). Especially from 2018, Russian officials have called for the easing of economic sanctions, with Russian deputy foreign minister Igor Morgulov going as far as to state that Moscow was only under obligation to abide by UN sanctions, not unilateral American punitive measures (Reuters 2018).

Even as Russia joined its permanent member peers at the United Nations Security Council in agreeing to tougher sanctions measures against Pyongyang, Moscow has also called for the DPRK to be allowed to pursue economic opportunities, condemning the use of unilateral sanctions from countries such as the US to target areas of economic exchange not covered by UN resolutions (Zakharova 2018, 82). The Russian Federation has managed to maintain one critical node of cooperation with the DPRK despite the increasingly restrictive nature of sanctions, namely in maintaining the right to use the port of Rason-Khasan. The Russian Federation maintains the right to ship coal to international markets via Rason-Khasan, which is crucial for Russia given the continued shift in the Russian coal export market toward Asia (Mochalnikov 2015, 3-4).

Although the Russian Federation has approved multilateral sanctions at the UN Security Council, unilateral sanctions against the DPRK have been a continued source of frustration for the Russian Federation. While the bulk of the complications stemming from unilateral sanctions that the Russian government and entities have faced have been due to US unilateral sanctions, Washington is by no means the sole source of frustration for the Kremlin's interests in this regard. In September 2013, North Korea and Russia opened a new rail line at Rason-Khasan after new track had been laid. Nevertheless, at that time South Korean firms, even with the "Eurasian Initiative" being discussed in Seoul, were reluctant to participate even in the Rason-Khasan special economic zone because of unilateral ROK sanctions (Pereslavtsev 2015, 7).

Russia agrees with the United States that there is an inherent danger that North Korea's possession of nuclear weapons poses, yet the Kremlin differs with Washington on how to go about resolving the issue (Lee and Severe 2017). Furthermore, the United States government has indicated that it does not believe the Russian Federation has been fully complying with or enforcing punitive economic measures. In the summer of 2017, the US Treasury department laid sanctions against Russian firms such as Ardis Bearings LLC over alleged links to the North Korean firm Tangun, which the US government asserts has ties to the DPRK's missile program (US Department of the Treasury Press Center 2017). In August 2018, the US Treasury Department, based on an American executive order, sanctioned Primorye Maritime Logistics and Gudzon Shipping, which 
Washington asserted had been complicit in transferring of refined petroleum products to North Korea. Russia is reported to continue supplying petroleum to North Korea via China, while North Korea has also traditionally received an abundance of coal from Russia (Lukin and Zakharova 2018, 3). In 2018, the Russian bank Agrosoyuz was blacklisted by the US Treasury Department pursuant UN Security Council resolutions for knowingly facilitating cash transfer into accounts on behalf of the North Korean Foreign Trade Bank (US Department of the Treasury Press Center 2018).

Indeed, in spite of US allegations of Russian failure to fully comply with sanctions, Moscow has consistently approved UN sanctions packages; in many ways inconveniencing the Kremlin's own economic interests. UNSCR 2094, passed after North Korea's third nuclear test in 2013, included provisions to prevent transfers of cash to the North Korean regime (United Nations Security Council 2013), a fact that has potential implications for the DPRK-Russia agreement to conduct trade in Russian rubles instead of US dollars. In 2016, the UN Security Council adopted two resolutions that placed economic sanctions on Pyongyang in light of North Korea's two successful nuclear tests that year. Resolution 2270, passed in March 2016 restricts the DPRK's ability to sell coal on the international market, while also cracking down on financial institutions affiliated with the Pyongyang regime. This resolution's implications for Russia's trade with North Korea include limiting the DPRK's abilities to compensate Russia for investments and deliveries through payments with natural resources, on which the DPRK's trade with Russia has been partially due to the lack of financial resources North Korea has. Another potential negative impact UNSCR 2270 expected to have, was that the stress placed on the North Korean economy could inhibit market reforms within the country, delaying the potential for Russian companies to increase investments in the DPRK (Toloraya 2016).

Allowance has been made, however for limited Russian involvement in North Korea's natural resources trade. Paragraph 26, Section A of Resolution 2321 (promulgated November 2016) replaced Paragraph 29 of UNSCR 2270, stating that other countries could continue exporting coal through Rason, provided they can prove that such transactions were not undertaken to generate revenue for the DPRK (United Nations Security Council 2017). Furthermore, in addition to approving sanctions at the UN, the Russian government has also supported international law with its own internal domestic policies. Following UNSCR 2270's passage in 2016, for example, Russian president Vladimir Putin signed a decree regulating North Korean financial activities inside the Russian Federation (Ukaz Prezidenta Rossiyskoy Federatsii 2016). The Russian government's decision to follow up on the UN resolution with a decree from the Kremlin as opposed to legislation passed in the Russian parliament may have been because the Kremlin wanted to bring Russia into a position of legally 
supporting sanctions as soon as possible (cf. Protysk 2004, 652). Likewise, in response to UN Resolution 2321, also promulgated in 2016, the Central Bank of Russia placed restrictions on the financial activities of both North Korean banks operating in Russia, as well as those of North Korean diplomats posted to the Russian Federation (Central Bank of the Russian Federation 2016).

In response to continued allegations of sanctions violations, in early 2019, the Russian government reported that while UN Resolution 2375 prohibited the continuation of joint firms between North Korea and other countries, the presence of North Korean firms' representative offices operating within the Russian Federation did not ipso facto violate United Nations provisions, particularly if individual firms had not been specifically blacklisted at the UN. The Russian government's response further cited provisions within Russian domestic law that governed the ability of foreign firms' representative offices to earn revenue (United Nations Security Council 2019).

Particularly since 2018, however the Russian government has called for a reduction of the multilateral sanctions laid against the DPRK. In August of that year, Valentina Matvienko, speaker of the Russian parliament's upper house, met with Kim Jong Un to commemorate the 70th anniversary of Moscow-Pyongyang ties. Matvienko later asserted that the North Korean leader requested Moscow's assistance in dealing with the negative effects of sanctions (Tass.com 2018a). Other experts have warned that additional sanctions could undermine not only Moscow's ties with North Korea but also the Kremlin's efforts at fostering trilateral cooperation involving North Korea, Russia and the ROK as well (Toloraya 2018).

Prior to the laying of UN sanctions, a significant portion (between a quarter and one-third) of Russian exports to North Korea was comprised of mineral fuels and oils. During Choe Ryong-hae's visit to Russia in 2014, the DPRK government confirmed it was willing to consider the possibility of serving as an energy conduit for Russia to be able to supply the ROK with natural gas, either via pipeline or through a rail connection involving a trans-Korean railway connected to the Trans-Siberian Railway (Karaivanov and Barannikova 2015, 19). UN Security Council Resolution 2375, however, passed in September 2017, placed restrictions on North Korea's ability to import natural gas, which has implications for economic cooperation between North Korea and Russia and their stated goal of implementing infrastructure that would allow for the Russian Federation to export fuel to the Korean Peninsula, either via pipeline or rail connection. Aforementioned UN resolutions banning North Korea from selling coal and iron ore, meanwhile, have undermined Russian plans to extract and sell North Korean natural resources in exchange for overhauling the DPRK's rail infrastructure, as well as Russian plans to invest in Russian companies based in the DPRK that focused on those areas (Zakharova 2016b, 221). 
While UN sanctions against the DPRK have undermined prospects for economic cooperation between North Korea and Russia that have not yet fully materialized; one long-standing and significant aspect of cooperation that sanctions have uprooted is the issue of North Korean laborers in the Russian Federation. In the summer of 2017, the DPRK claimed to have successfully tested an intercontinental ballistic missile (ICBM). The US Department of Defense affirmed Pyongyang's claims that the projectile launched was indeed an ICBM. At the United Nations Security Council, however, the Russian Federation initially refused to concede that it was indeed an ICBM. Nevertheless, Moscow ultimately lent its support for UN Resolution 2397 in December 2017, which stipulates that member states must repatriate North Korean workers on employment contacts by December 2019 (United Nations Security Council 2017). This measure added to the provisions of a United Nations Security Council Resolution 2375, passed on September 11, 2017, prohibiting countries from granting new work contracts to DPRK citizens currently employed in other countries.

North Korean citizens have long been present in Russia, with post-Soviet Russia making special accommodations for DPRK citizens employed on Russian soil. In 1997, Moscow and Pyongyang inked an agreement to allow North Korean citizens to legally work in Russia under a specific visa regime (Vashchuk 2012, 80), while in 2013, the Russian government augmented the quota of work permits for North Korean laborers to a maximum of 35,000 (Zakharova 2016a, 158). The provincial economies of the Russian Far East highlight the need for unskilled and semi-skilled manual laborers. In Amur Province for example, agriculture, industry and construction comprise $45.4 \%$ of the provincial gross product. Trade, on the other hand, constitutes just over 12\% (Regional'noye Pravitel'stvo Amurskoy Oblasti n.d.).

Just as the UN has moved to curb the employment of North Koreans, the Amur provincial government quadrupled its quota for foreign workers, partially due to increased economic opportunities in the province stemming from an increase in local investment (Amurskaya Pravda 2018). The provincial ministry of labor in Khabarovsk province meanwhile set a quota of just over 7,000 foreign laborers. Bracing for the impact of regulations on hiring North Koreans, 85 percent of the foreign workers in Khabarovsk under the extended quota on foreign employees will come from China, according to Russia's Ministry of Economic Development (Vostok Media 2018). Aware of the effects the phasing out of North Korean workers would have on Primorye's local economy, provincial governor Andrei Tarasenko requested that the Russian Ministry of Labor make exceptions for nearly 10,000 North Korean workers throughout 2018, in contravention of UN sanctions. Moscow, however, denied the governor's petition (The Moscow Times 2018). Ahead of the summit between Kim Jong Un and Vladimir Putin in April 2019, meanwhile, the Russian government had 
reported to the UN that just over 11,000 North Korean citizens in Russia on work contracts remained (The Moscow Times 2019).

\section{CONCLUSION}

For the Russian Federation, the Korean security crisis has forced the Kremlin to contend with trade-offs in the way it approaches its ties with Pyongyang balancing between cooperating with other states in inducing the DPRK to modify its behavior and pursuing closer economic ties with North Korea. Thus far it has opted to pursue punitive measures against North Korea, even as Russia has not only faced actions from the United States over alleged compliance failures, but has also undermined its own ambitions for developing the Russian Far East. Although the Russian Federation's position on North Korea's WMD program is largely ensconced in Russia's global-level policies on nonproliferation, realities within the Asian section of the Russian Federation, and how the Russian Far East relates to other East Asian states, partially shape the Kremlin's stance toward the DPRK. Nevertheless, even as Moscow has assented to punitive economic measures, the Russian government of late has insisted that economic restrictions against the DPRK be loosened.

Dismantling sanctions against North Korea bodes well with Russian interests, yet UN sanctions, will likely remain in place for as long as the US, and to a lesser extent China, assess that punitive economic measures are necessary to curb the DPRK's provocative behavior. For the Russian Federation, therefore, the most plausible course of action in balancing between the need to comply with sanction and its desire for economic cooperation with the DPRK include focusing on investment and infrastructure reform that allow for greater use of the Rason-Khasan port, as well as promoting trilateral cooperation between the DPRK, Russia and South Korea, particularly under the latter's "New Northern Policy." Concurrent with Russian efforts to strive for continued legitimate economic cooperation in both bilateral and multilateral formats, the Russian Federation can be expected, in the coming years, to continue using its diplomatic clout at the $\mathrm{UN}$ to push for the loosening of sanctions and perhaps even using its veto power to prevent new sanctions packages that continually harm its interests from being passed. Nevertheless, as this paper demonstrates, the odds are not in Moscow's favor in this regard, and the Kremlin will be hard-pressed to achieve any of its goals regarding sanctions against Pyongyang. 


\section{REFERENCES}

Akkalaeva, Veronika. 2014. "Takogo prokta net i ne budet." Gazeta.ru.

Amurskaya Pravda. 2018. "Migranty iz Severnoy Korei pokinut Priamur'ye do kontsa sleduyushchego goda.” Amurskaya Pravda. February 8, 2018, accessed February 18, 2018. https://www.ampravda.ru/2018/02/08/080068.html.

Bardal', A.B., O.V. Demyanenko, Y.V. Dyomina, and N.V. Lomakina. 2018. "K voprosu o trekhstoronnem ekonomicheskom sotrudnichestve Respubliki Koreya, KNDR i Rossiya." Regionalistika 5(6): 180-190.

Blank, Stephen. 2015. "Russia and the Two Koreas in the Context of Moscow's Asian Policy." Korea Economic Institute of America Academic Papers Series: 60-76.

Denisov, Valeriy Iosifovich. 2009. "Koreyskaya problema v sovremennoy vneshney politike Rossii." Vestnik RGGU. Seriya Politologiya. Istoriya. Mezhdunarodnyye otnosheniya. Zarubezhnoye regionovedeniye. Vostokovedeniye 14: 102-118.

Denisov V.I. 2010. “Osobennosti vneshnepoliticheskogo protsessa v Koreyskodemokraticheskoy Respublike.” Vestnik MGIMO Universiteta 1: 237-244.

Denisov, V. I. 2013. "Pozitsiya Rossii v voprose o mirnom dogovore po Koreye." Vestnik MGIMO Universiteta 3(30): 45-49.

Fedorova, Anastasiya Alekseyevna. 2018. "Rol' problemy KNDR dlya regiona Vostochnoy Azii i eye vliyaniye na Rossiyskuyu Federatsiyu." Vypusknaya bakalavrskaya rabota po napravleniyu podgotovki: Zarubezhnoye regionovedeniye 41(03.01): 1-85.

Gabuev, Alexander. 2017. "A Russian Perspective on the Impact of Sanctions." Korea Economic Institute of America Academic Papers Series: 247-257.

Karaivanov, Alexey A. and Anastasia O. Barannikova. 2015. "Energy Sector: the Possibilities of Resumption of the Russian-North Korean Cooperation." Russian Far East and Korean Peninsula 5(1): 18-20.

Klimenko, Anatoliy Filippovich. 2014. "Rossiya i Kitay v sisteme bezopasnosti Severo-Vostochnoy Azii." Kitay v mirovoy i regional'noy politike. Istoriya i sovremennost' 19: 31-50.

Kozyrev, Vitaly. 2014. "Russia's new global vision and security policy in East Asia." Russia and East Asia edited by Tsuneo Akaha and Anna Vassilieva, 41-65. Abingdon-on-Thames, United Kingdom: Routledge.

Lankov, Andrei. 2018. Kak Rossii otnosit'sya $k$ novym sanktsiyam protiv Severnoy Korei. Carnegie Moscow Center. Accessed June 7, 2018. https://carnegie.ru/ commentary/75259.

Lee, Rens and William Severe. 2017. Russia and Crisis Management on the Korean Peninsula (E-Notes) Foreign Policy Research Institute. Accessed March 22, 2018. https:/www.fpri.org/article/2017/11/russia-crisis-management -korean-peninsula/. 
Lektzian, David, and Mark Souva. 2007. "An institutional theory of sanctions onset and success." Journal of Conflict Resolution 51(6): 848-871.

Lukin, Artëm Leonidovich. 2017. "Rossiya i severokoreyskiy yadernyy krizis." Izvestiya Vostochnogo instituta 34(2): 59-67.

Lukin, Artyom, and Liudmila Zakharova. 2018. "Russia-North Korea Economic Ties: Is there more than meets the eye?" Orbis 62(2): 244-261.

Luzyanin, Sergei and Lyudmila Zakharova. 2015. "Vzaimodeystviya Rossii i Kitaya na Koreyskom poluostrove: Vyzovy i vozmozhnosti." Obozrevatel'-Observer October 2015. 309(10): 24-33.

Mankoff, Jeffrey. 2015. "Russia's Asia Pivot: Confrontation or Cooperation?" Asia Policy 19: 65-88.

Mishin, V. Y. 2016. "Rossiya-KNDR: vzaimniy poisk putey integratsii. Vozmozhnosti i perspektivy." Rossiya i ATR 92(2): 62-71.

Mochalnikov, Sergey. 2015. "Current status and development prospects of coal industry in Russia." Ministry of Energy of the Russian Federation. Last modified September 2015, accessed June 27, 2017. http://www.jcoal.or.jp/ coaldb/shiryo/material/upload/1-12speech\%203\%20Russia\%20Mr.\%20M ochalnikov.pdf.

The Moscow Times. 2017. "Embassy in Pyongyang Points to North Korean Atlas Showing Crimea as Russia." The Moscow Times. October 13, 2017, accessed May 1, 2019. https://www.themoscowtimes.com/2017/10/13/russiaposts-reminder-that-north-korea-recognizes-crimea-as-russian-a59265.

The Moscow Times. 2019. "Russia Tells UN It Sent Home Over Half of North Korean Workers in 2018." The Moscow Times. March 26, 2019, accessed April 25, 2019. https://www.themoscowtimes.com/2019/03/26/russia-tells-unit-sent-home-over-half-nkorean-workers-in-2018-a64949.

Oelsner, Andrea. 2005. "(De) Securitisation Theory and Regional Peace: Some Theoretical Reflections and a Case Study on the Way to Stable Peace." EUI Working Papers RSCAS No. 2005/27.

Park, Chang Kyoo, Er-Win Tan, and Geetha Govindasamy. 2013. "The Revival of Russia's Role on the Korean Peninsula." Asian Perspective 3(1): 125-147.

Park, Sangyŏn. 2016. "Najinhang pudusayonggwŏne taehan rŏsiawa chunggugŭi taebukhyŏpsang pigyo: hyŏpsang kujo, insik mit taeŭngjŏllyagŭl chungsimŭro." (Ph.D. Dissertation, Seoul National University): 1-128.

Pereslavtsev, N. I. 2015. "About the prospects of Russian Participation in the Railway Freight Transit Through Korean Peninsula." Russian Far East and Korean Peninsula 5(1): 5-17.

Primamedia.ru. 2014. "Dogovory Rossii i KNDR: raschety v rublyakh i oblegchennyy vizovyy rezhim.” Primamedia.ru. June 5, 2014, accessed May 1, 2019. https://primamedia.ru/news/362889/.

Primamedia.ru. 2018. "Severokoreyskim rabochim v Primor'ye dadut vremya 
zarabotat' na dorogu domoy.” Primamedia.ru. February 8, 2018, accessed February 8, 2018. https://primamedia.ru/news/667951/.

Protysk, Oleh. 2004. "Ruling with Decrees: Presidential Decree Making in Russia and Ukraine." Europe-Asia Studies 56(5): 637-660.

Regional'noye Pravitel'stvo Amurskoy Oblasti. N.d. "O Nashem Regione: Ekonomika.” Accessed March 1, 2018. http://www.amurskayaobl.ru/ about/economy/.

RIA Novosti. 2015. "Rossiya i KNDR sozdadut delovoy sovet." RIA Novosti. January 22, 2015. Accessed May 5, 2019. https://ria.ru/20150122/10436 86178.html.

Samoilov, Vasiliy Dmitriyevich and Anatoliy Dmitriyevich Sitnikov. 2018. "Denyuklearizatsiya Severnoy Korei: voenno-politicheskie aspekty." Vestnik ekonomicheskoy bezopasnosti No. 3(2018): 192-195.

Shin, Beom-shik. 2014. "Post-Cold War Russian foreign policy and the Korean Peninsula." In Russia and East Asia: Informal and gradual integration edited by Tsuneo Akaha and Anna Vassilieva. Abingdon-on-Thames, United Kingdom: Routledge.

Stepanov, N. S. 2018. "Ekonomicheskaya politika Rossii v otnoshenii stran Vostochnoy i Yugo-Vostochnoy Azii." Disskusiya 88(3): 100-108.

Surinov, A. E., et al. 2018. "Vneshneekonomicheskaya Deyatel 'nost'." In Rossiya $v$ tsifraxh. Federal'naya sluzhba gosudarvstayennoy statistiki.

Tass.com. 2018a. "Kim Jong-un expects Russia to help ease sanctions on North Korea - speaker." Tass.com. September 10, 2018, accessed September 11, 2018. http://tass.com/politics/1020770.

Tass.com. 2018b. "UN approves creation of humanitarian exemption mechanism regarding sanctions against DPRK." Tass.com. August 7, 2018, accessed May 3, 2019. http://tass.com/world/1016252.

Tass.com. 2019. "Russian-North Korean trade turnover drops by half in 2018 due to sanctions." Tass.com. April 23, 2019, accessed April 29, 2019. http://tass.com/ economy/1055196.

Toloraya, Georgy. 2016. UNSCR 2270: A Conundrum for Russia. 38 North. March 5, 2016, accessed April 26, 2019. https://www.38north.org/2016/03/gtoloraya030516/. Toloraya, Georgy. 2018. Klaster sotrudnichestva mezhdu Rossiyey, Severnoy $i$ YUzhnoy Koreyey. Valdai Club. September 12, 2018, accessed 27 March 2019. http://ru.valdaiclub.com/a/highlights/klaster-sotrudnichestva/.

Troyakova, Tamara Gavrilova. 2016. "Rol' rossiyskogo Dal'nego Vostoka v razvitii otnosheniy s KNDR.” Izvestiya Vostochnogo instituta (31): 45-54.

Ukaz Prezidenta Rossiyskoy Federatsii ot 29.12.2016 г. No. 729. 2016. O merakh po vypolneniyu rezolyutsii Soveta Bezopasnosti OON 2270 ot 2 marta 2016 g. Last modified December 29, accessed June 20, 2017. http://www.kremlin.ru/acts/bank/41624. 
United Nations Security Council (UNSC). 2013. Resolution 2094 (2013)." March 7, 2013, accessed April 28, 2019. http://www.securitycouncilreport.org/ atf/cf/\%7B65BFCF9B-6D27-4E9C-8CD3-CF6E4FF96FF9\%7D/s_res_20 94.pdf.

United Nations Security Council (UNSC). 2016. Security Council Strengthens Sanctions on Democratic Republic of Korea, Unanimously Adopting Resolution 2321, 7821st Meeting(am). November 30, 2016, accessed December 14, 2017. https://www.un.org/press/en/2016/sc12603.doc.htm.

United Nations Security Council (UNSC). 2019. Letter dated 1 February 2019 from the Panel of Experts established pursuant to resolution 18 (2009) addressed to the Chair of the Security Council Committee established pursuant to resolution 1718 (2006). March 12, 2019, accessed April 27, 2019. https://www.securitycouncilreport.org/atf/cf/\%7B65BFCF9B-6D274E9C-8CD3-CF6E4FF96FF9\%7D/s_2019_171.pdf.

United Nations Security Council (UNSC). 2017. Resolution 2397: Non-proliferation/ Democratic People's Republic of Korea, Security Council Distr.: General 22 December 2017 Resolution 2397. December 22, 2017, accessed January 18, 2018. http://unscr.com/en/resolutions/2397.

US Department of the Treasury Press Center. 2017. "Treasury Sanctions Suppliers of North Korea's Nuclear and Weapons Proliferation Programs." Last modified June 1, 2017, accessed September 25, 2017. https://www.treasury. gov/press-center/press-releases/Pages/sm0099.aspx.

US Department of the Treasury Press Center. 2018. Treasury Targets Russian Bank and Other Facilitators of North Korean United Nations Security Council Violations. August 3, 2018, accessed April 25, 2019. https://home. treasury.gov/news/press-releases/sm454

Vashchuk, A. S. 2012. "Trudovyye migranty iz KNDR na rossiyskom Dal'nem Vostoke vo vtoroy polovine XX - nachale XXI veka." Gumanitarnyye issledovaniya $v$ Vostochnoy Sibiri i na Dal'nem Vostoke 1(17): 180-190.

Veka, E. A. 2015. “ $\mathrm{K}$ voprosu o sotsial'no-ekonomicheskikh i politicheskikh protsessakh v KNDR pri Kim Chen Yne i ikh vliyanii na rossiyskoseverokoreyskiye svyazi." Rossiya i ATR 1(87): 180-190.

Weitz, Richard. 2010. "Russia and the Koreas: Past policies and future possibilities." Academic Paper Series 5(2): 1-18.

Weitz, Richard. 2015. "Russian Policy toward North Korea: Steadfast and Changing." Korean Unification Studies 24(3): 1-30.

Zakharova, Liudmila. 2016a. "Economic cooperation between Russia and North Korea: New goals and new approaches." Journal of Eurasian Studies 7(2): 151-161.

Zakharova, Liudmila. 2016b. "RussiaNorth Korea Economic Relations." Joint USKorea Academic Studies, Korea Economic Institute 27: 211-222. 
Zakharova, Lyudmila Vladimirovna. 2018. "Podkhody k uregulirovaniyu yadernogo krizisa na Koreyskom poluostrove: ekonomicheskiy aspekt." Vestnik MGIMO Universiteta 62(5): 71-91.

Zhebin, Aleksandr. 2013. "Rossiya-KNDR: sosedey ne vybirayut." In Nezavisimaya Gazeta. October 14, 2013. Accessed September 27, 2015. http://www.ng.ru/ courier/2013-10-14/9_rus_kndr.html. 